\title{
Analysis of Significant Factors Influencing the Amount of Collected Forest Berries in the Czech Republic
}

\author{
Marcel Riedl ${ }^{1}$, Vilém Jarský ${ }^{1}$ (D), Daniel Zahradník ${ }^{1}$, Petra Palátová ${ }^{1, *(D)}$, Roman Dudík ${ }^{1}(\mathbb{D}$, \\ Jitka Meňházová ${ }^{2}$ and Luděk Šišák ${ }^{1}$ \\ 1 Faculty of Forestry and Wood Sciences, Czech University of Life Sciences Prague, Kamýcká 129, \\ 16500 Praha 6-Suchdol, Czech Republic; riedl@fld.czu.cz (M.R.); jarsky@fld.czu.cz (V.J.); \\ zahradnik@fld.czu.cz (D.Z.); dudik@fld.czu.cz (R.D.); sisak@fld.czu.cz (L.Š.) \\ 2 Faculty of Forestry and Wood Technology, Mendel University in Brno, Zemědělská 3, \\ 61300 Brno, Czech Republic; jitka.menhazova@mendelu.cz \\ * Correspondence: palatovap@fld.czu.cz; Tel.: +420-22438-3702
}

Received: 17 September 2020; Accepted: 15 October 2020; Published: 20 October 2020

\begin{abstract}
Bilberries (Vaccinium myrtillus L.), raspberries (Rubus idaeus L.), blackberries (Rubus fruticosus L.) and cowberries (Vaccinium vitis-idaea L.) are the most important forest berries collected in the Czech Republic (CZ). The average annual value of these collected berry species is estimated to be worth more than EUR 86 million at 2018 prices. The data concerning the collection and use of forest fruits have been systematically collected in a highly detailed structure since 2008, which enables the application of the advanced statistical methods used in this paper. The results of the analyses inter alia demonstrate that collecting forest berries is not only an important recreational activity, but it has an important economic effect. Therefore, this article also deals with the collection of forest fruits, especially bilberries, as a potentially important non-wood forest product (NWFP) for sustainable forest management and also analyses the external factors influencing the total annual amount of collected forest berries. A deeper knowledge of the customer and his or her behaviour-customer insight-are prerequisites for the proactive management of forest ecosystems. The first step to "berry picker insight" is to learn more about the demand, its structure and factors which influence this demand. Thus, one of the research questions concentrates on the analysis of the sociodemographic characteristics of the berry picker that are relevant for explaining the amount of collected forest berries in the Czech Republic. Knowledge of these factors can contribute to a more effective application of marketing methods for shaping and influencing the demand so that, in terms of time and place, it is more in line with the supply, which is limited by the natural conditions, growing season and production potential of forest ecosystems.
\end{abstract}

Keywords: forest berries; socio-economic importance; customer insight; Czech Republic; ecosystem services

\section{Introduction}

Forest ecosystems provide a range of services and products that meet the needs of society and individuals [1-4]. As studies have shown [5-9], many ecosystem services are associated with non-wood forest products (NWFPs). Although the economy, forestry, agriculture, rural development and other sectors may address NWFPs, usually, there is not one sector explicitly dealing with these issues [10]. The demand for NWFPs is strongly linked to societal trends and cultural preferences [11]. Due to the role and economic potential in the utilisation of NWFPs, there is a need, and an increasing interest, in monitoring their market volume and values both on a national and an international level [12]. 
There is also growing concern over the amount of forest crops harvested due to the level of the organic production and the burden on the forest environment in many countries, both in North America and in Europe.

The favourable impact of NWFPs on human health is stressed by [13], and the high content of antioxidants in wild berries is addressed in [14]. Grivins [15] mentioned that the Chinese herbal market demands, for example, large quantities of wild bilberries owing to their beneficial health properties. According to [16], bilberries decrease the risk of cardiovascular disease, diabetes (type 2) and they are helpful in weight maintenance.

According to [17], wild berries are collected by the largest share of European households (20.7\%) followed by wild mushrooms (19.7\%). Although picking berries could principally be thought as a provisioning service [18], it is often categorised as a recreational forest activity due to the everyman's rights [19]. Some of these services, such as picking berries and mushrooms, may also be regarded as supporting cultural ecosystem services, including outdoor recreation and promoting mental and physical health [20]. Saarikoski et al. [21] emphasised that the aesthetic qualities of forests strongly influence the berry picking experience as well as other recreational activities.

From a geographical point of view [17], the importance of picked NWFPs can be found in some Slavic (e.g., Russia, Bulgaria, Poland, Serbia), Baltic (Latvia, Lithuania, Estonia) or Nordic (Finland and Sweden) nations, which have been accentuated upon in the eastern and northern European countries publications of $[22,23]$ or [24], in which they concentrated on the value of the berries and mushrooms in Slovakian forests. In Finland, wild berry picking has kept its role as one of the most prevalent forest-related activities [25] and large quantities of berries are picked annually; the estimated amount is 42 million $\mathrm{kg}$ per year [26]. However, as stressed in [27], for example, the lack of any systematic research concerning the quantities of the harvested wild berries is apparent. According to [28], one of the challenges for internationally comparable ecosystem assessments is that the available data sets and used measures are different in various European countries. Muir et al. [29] directly states: “ ... information on NWFPs is patchy and incomparable across countries. Undoubtedly, the sheer number of products and different end uses coupled with challenges surrounding non-standard units of measurement and terminology issues all make NWFP quantification problematic."

Berry picking, however, does not provide a similar market value for the forest owner as the wood-based biomass does, but the management of the forests considerably differs between these services and the frequency and intensity of the forest visits [30]. In the situation where the prices of wood products (mainly roundwood) are decreasing [31], especially since 2017, due to the large bark beetle outbreaks in most parts of Central Europe [32,33], forest owners must look for other sources of income, including changing the forest management from wood to non-wood production, or must politically promote the introduction of payments for ecosystem services. Lovrić et al. [17] evaluated the NWFP in 28 European countries and suggested that one should consider the co-production of wood and NWFPs, especially in Central Europe.

At present, the effect by which forest fruits, especially bilberries, respond to changes in forest management is already well described [34-37]. However, such measures can only be realised if the offeror (e.g., the forest owner) has enough information about his/her potential customers (i.e., the pickers). Laughlin [38] refers to the term "customer insight" as "A non-obvious understanding about your customers, which if acted upon, has the potential to change their behaviour for mutual benefit". This paper deals with the collection of forest fruits, especially bilberries, as a potentially important NWFP for sustainable forest management in the Czech Republic (CZ). The first step to "berry picker insight" is to learn more about the demand, its structure and the factors which influence this demand. For the analyses of the significant factors (including the sociodemographic characteristics of the berry pickers) related to the forest fruit collection in the $C Z$, the following research questions (RQ) are used:

RQ1. How is the total amount of collected forest fruits that are collected each year of the analysed period distributed among the berry pickers? 
RQ 2. What are the personal characteristics of the berry picker that are relevant in explaining the amount of collected forest berries in the Czech Republic?

RQ 3. How has the (total) amount of collected forest fruits varied during the analysed period of 25 years?

RQ 4. What are the main meteorological factors influencing the total annual amount of collected forest berries?

\section{Materials and Methods}

\subsection{NWFP in the Czech Republic}

According to the Czech Forest Act, the free collection of NWFPs is allowed on $92 \%$ of the forest areas (all the forests, irrespective of the ownership, except military forests and strongly protected natural preserves and zones of national parks) [39]. Historically, research on the issue of assessing the socio-economic significance of NWFPs in the CZ was initiated in 1993, as presented by [40]. The popularity of NWFP collecting and especially the consumption of mushrooms and forest berries in the Czech Republic is considerable [41]. The most commonly harvested forest fruits in CZ include mushrooms, bilberries, cowberries, raspberries and blackberries [42].

A detailed analysis on the socio-economic effects of the non-market non-timber forest products in the CZ has been presented by [43]. The main data serving as the basis for a more detailed statistical analysis of the collection of forest berries and their harvesters, for our article, have been obtained using the same methodology (more details can be found in Section 2.2: Data Collection) as that of the data on mushroom collecting in the article by [43] and have been extended by the data from 2014 to 2018 . Figure 1 shows the total amount of harvested forest berries in the years 1994-2018.

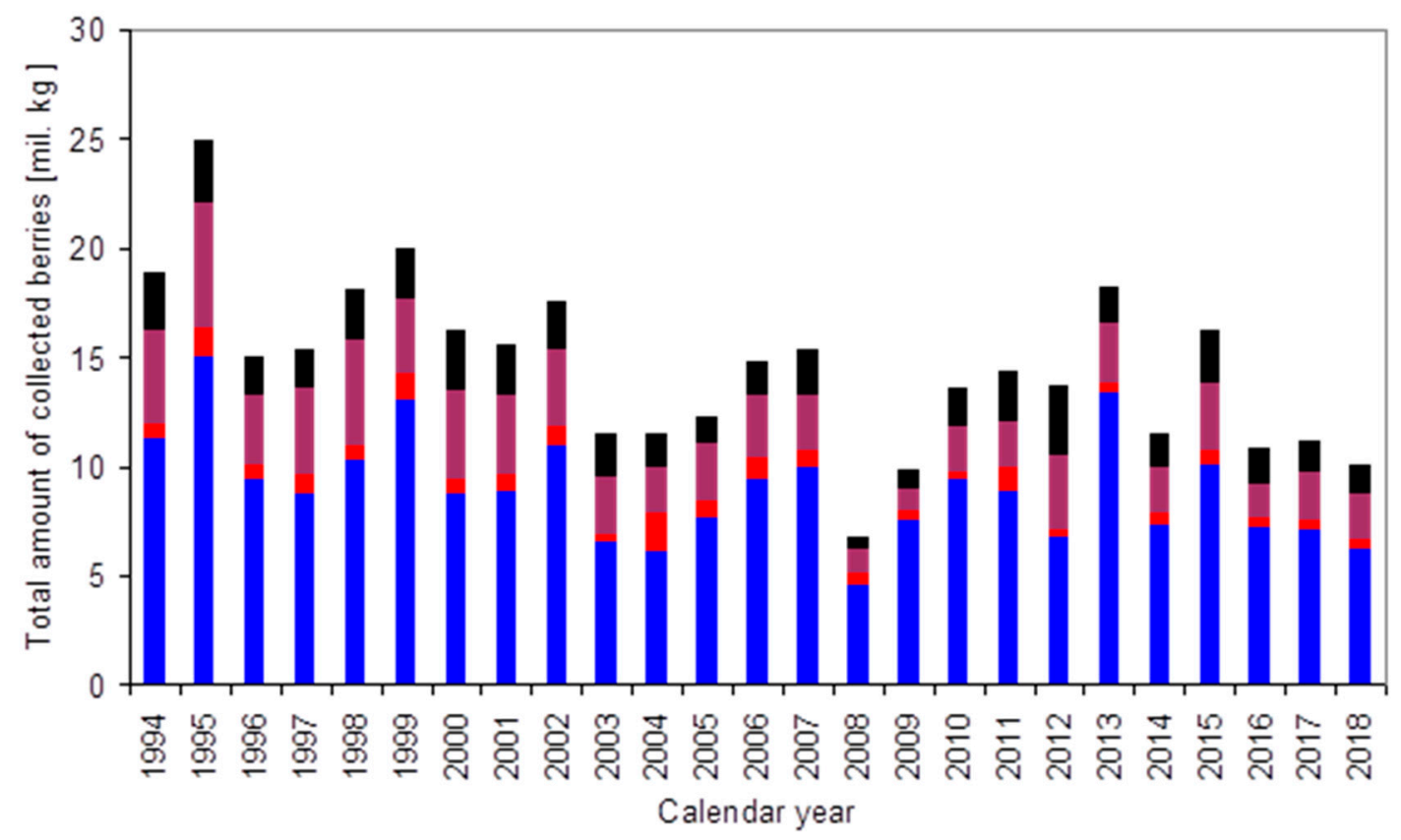

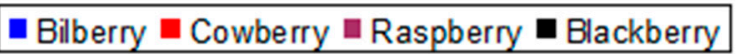

Figure 1. The total amount of the collected forest berries (bilberries, cowberries, raspberries and blackberries) in the Czech Republic (CZ) (millions of kg) in the period 1994-2018 (Sisak et al. 2016 [43], extended).

The coefficient of variation, also known as the relative standard deviation, mathematically defined, in statistics, by the ratio of the standard deviation by the mean value (standard deviation/mean), 
is considered to be a normalised measurement of the dispersion of the data, see, e.g., [44]. In Table 1, the coefficient of variation is calculated for each time series shown in Figure 1. The values of the variation coefficient that approach $30 \%$ indicate considerable variability in the analysed data, see [45].

Table 1. The coefficient of variation of the total amount of the collected forest berries (bilberries, cowberries, raspberries and blackberries) in the CZ in the period 1994-2018.

\begin{tabular}{ccccc}
\hline & Bilberries & Cowberries & Raspberries & Blackberries \\
\hline Mean (millions of kg) & 8.972 & 0.720 & 2.928 & 1.912 \\
Standard deviation & 2.462 & 0.352 & 1.141 & 0.609 \\
Coefficient of variation (in \%) & 27.4 & 48.9 & 39.0 & 31.9 \\
\hline
\end{tabular}

\subsection{Data Collection}

The research area covers the whole of the Czech Republic, a Central European country. The CZ occupies an area of $78,863 \mathrm{~km}^{2}$. The $C Z$ forestland covers $26,717 \mathrm{~km}^{2}$, i.e., $33.9 \%$ of the total area of the CZ. For further details about the natural conditions of the CZ, see, e.g., [46]. The extent of the forest area accessible to the public and the number of inhabitants basically stayed the same during the analysed period of 1994-2018. According to the Czech Statistical Office [47], there was a 2.81\% increase in the number of inhabitants during the whole 25-year period, which is negligible.

Over the whole period of 1994-2018, standardised questions related to the amount of harvested wild berries and mushrooms were used in personal interviews. For the period of 1994-2007, only the aggregated data estimating the total amount and the total value of the collected forest berries are available. This means that for the period of 1994-2007, the data are not available from the individual respondents, but only the calculations of the total value and quantity for each species of collected forest berries are available. Since 2008, the survey has been conducted by the hired research agency Stemmark, which, as a member of European association research agencies (ESOMAR), meets its strict criteria regarding ethics and a professional approach to market research. So, for the period 2008-2018, the socio-economic data of the individual respondents including the collected amount and price per $\mathrm{kg}$ of the collected forest berries are available. The questioning was conducted using a computer-aided personal interview method (CAPI) on a representative group of respondents as a part of the omnibus research. A network of approximately 250 trained interviewers allowed one to achieve the desired representativeness of the research sample using the original standardised questionnaire [43]. In the individual years of the period 2008-2018, there was a regular change in the respondents in the omnibus research. The description and advantages of the omnibus research method are explained, e.g., by [48]. The respondents were selected on the basis of their gender, age, education, size of the municipality and region of residence (a so-called quota sample) which ensures the representativeness of the sample with respect to these criteria and which is also an important prerequisite for the subsequent statistical analyses. Between 2008 and 2018, the number of respondents in the annual survey ranged between 1000 (2013) and 1087 (2011). For the entire monitored period, more than 1000 respondents were interviewed annually. The total number of respondents for the period 2008 to 2011 was 11,254, which makes this research unique on a global perspective. The standard error estimate [49] associated with this sample size is $0.47 \%$. The data contained within are the main source for the analyses and graphs presented in this paper. The estimates concerning the total quantity of the collected berries are derived from the results of these surveys and have been published in yearly reports on the state of the forest and forestry of the Czech Republic [50]. Although the division of the Czech Republic into regions has changed several times over the last 25 years, the division used since the beginning of the research in 1994 has been retained (Figure 2). 


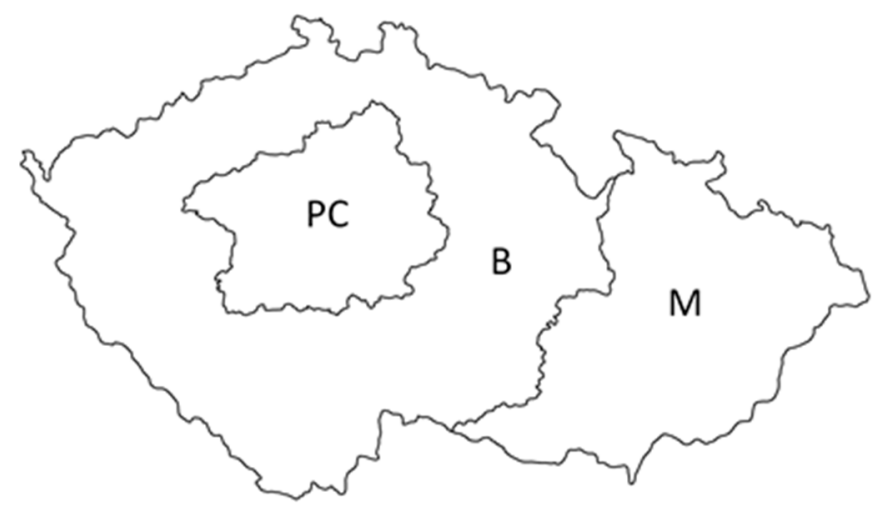

Figure 2. Regions in the Czech Republic. PC-Prague and Central Bohemia, B-Bohemia without the central region, $\mathrm{M}-$ Moravia.

\subsection{Statistical Methods}

The statistical analysis of the data was carried out in 3 steps:

1. The data obtained from the forest berries pickers in each year from 2008 to 2018 were analysed using the Gini coefficient to determine the degree of unevenness in the distribution of the quantity of collected forest fruits between the berry pickers.

2. Using the data for the period 2008 to 2018, the dependence of the volume of the harvested forest fruits on the sociodemographic characteristics of the individual respondents was analysed using a proportional odds model. Graphical methods are also used for clarity-such as a Lorenz curve in the case of the distribution of the collected quantity of bilberries and mosaic displays to show the relationships of the collected quantity and selected sociodemographic characteristics.

3. The total volume of the harvested bilberries, depending on external factors, was analysed using a linear model. In this case, it was possible to use the data for the entire monitored period 1994-2018. In this third step, the collection of bilberries was used for the analysis, due to its importance and the number of respondents stating non-zero amounts of collecting berries (about 38\%).

\subsubsection{Distribution of Berries Collected in CZ}

The Gini coefficient and Lorenz curve were used in order to evaluate the distribution of the berries collected among the respondents' households.

The Gini coefficient [51] is defined as:

$$
G=\frac{\sum_{i=1}^{n} \sum_{j=1}^{n} X_{i}-X_{j}}{2 n^{2} \bar{X}}
$$

where $X_{i}$ is the amount of the berries collected by $i$-th respondent, $\bar{X}$ is the average amount of berries collected by one respondent and $n$ is the number of respondents.

The Gini coefficient is a measure of the univariate inequality, which arises as a special case of the concentration index, when the inequality is measured by the same variable that is used for the ranking; see [52]. The statistical conclusions based on the Gini index are often used for measurement inequalities in income distribution [53] or as a poverty measurement [54]. Sadras et al. [55] use the Gini index to assess the yield inequality in yield crops. We employed the Gini index to measure the inequality in the collection of forest berries. The values of the index range from 0 to 1 . The larger the Gini index value, the more unequal the distribution of the collected berries is.

Whereas the Gini coefficient summarises the information about the inequality into one number, the Lorenz curve [56] gives one a more detailed insight. The $\mathrm{Y}$ axis of the Lorenz curve refers to the 
cumulative outcome proportions of the population members ranked by the values of $X$. Formally, in a finite population, the Lorenz curve of $X$ can be defined as:

$$
L_{X}(p)=\frac{\sum_{i=1}^{n} X_{i} I\left(X_{i} \leq Q_{X}(p)\right)}{\sum_{i=1}^{n} X_{i}}
$$

where $n$ is the number of the observed values, $Q_{x}(p)$ is the $p$ quantile of the distribution of $X, I(\mathrm{~A})$ is an indicator function equal to 1 if $A$ is true and 0 otherwise [52,57].

\subsubsection{Analysis of Personal Factors Influencing the Amount of Berries Collected in the $\mathrm{CZ}$}

Unlike the amount of collected berries stated by the respondents, many other variables referring to the respondent's status do not comply with the requirements of a standard linear model. Due to this fact, the sociodemographic characteristics of the individual berry pickers were categorised in Table 2 using the categorical variables: "sex, age, size of residence (res.) or region" as explanatory variables for the dependent variable "the amount of collected berries" in the so-called proportional odds model (3) proposed by [49].

$$
\operatorname{logit}\left(P\left(Y_{i} \leq j\right)\right)=\log \frac{p_{i, 1}+\ldots+p_{i, j}}{p_{i, j+1}+\ldots+p_{i, J}}=\beta_{0, j}+\sum_{k=1}^{m} \beta_{k} x_{i, k} \quad j=1,2, \ldots, J-1
$$

where $p_{i, j}$ is the probability that the dependent variable $Y_{i}$ (of $i$-th measured object) takes the value $j, p_{i, j}=P\left(Y_{i}=j\right), J$ is the number of possible values of the dependent variable, $\mathbf{x}_{i, 1}, \mathrm{x}_{i, 2}, \ldots, \mathrm{x}_{i, m}$ are explanatory variables for the $i$-th object and $\beta_{0,1}, \ldots, \beta_{0, J}, \beta_{1}, \ldots, \beta_{m}$ are the regression coefficients.

Table 2. The variables and their values.

\begin{tabular}{cccccc}
\hline Age & Sex & Education & $\begin{array}{c}\text { Size of Residence } \\
\text { (Number of } \\
\text { Citizens) }\end{array}$ & Region & $\begin{array}{c}\text { Collected } \\
\text { Amount } \\
\text { (in kg/Year) }\end{array}$ \\
\hline 15-25 years & Male & Ed. 1: Primary & Size 1: $\leq 4999$ & $\begin{array}{c}\text { B: Bohemian without } \\
\text { the central region }\end{array}$ & 0 \\
\hline 26-55 years & Female & $\begin{array}{c}\text { Ed. 2: } \\
\text { Secondary }\end{array}$ & Size 2: 5000-19,999 & M: Moravian & $0.01-2.00$ \\
\hline $56-70$ years & $\begin{array}{c}\text { Ed. 3: College } \\
\text { or university }\end{array}$ & Size 3: 20,000-99,999 & $\begin{array}{c}\text { PC: Prague, Central } \\
\text { Bohemian region }\end{array}$ & $2.01-5$ \\
\hline $71+$ years & & Size 4: $\geq 100,000$ & & $5.01-10.00$ \\
\hline
\end{tabular}

Program R [58], namely the polr function in R's MASS package [59], was used in order to evaluate the model based on Equation (3). The polr function provides both the estimates of the coefficients $p$ and the test statistics for the hypotheses $\mathrm{H} 0: \beta_{i}=0, i=1,2, \ldots, k$, testing. The distribution of these test statistics is asymptotically normal [49], therefore, the corresponding significance levels were computed by:

$$
\text { p-value }=2(1-F(|T|))
$$

where $T$ is the value of the test statistics and $F$ is the distribution function of the standard normal distribution.

The score test for proportional odds (PO Score Test) [60] was used in order to evaluate the significance of the entire model. 
All the data regarding the collection of forest berries for the period 2008-2018, i.e., 11,254 entries, were categorised and analysed by the model (3). For this period, the personal characteristics of the berry pickers are available.

The statistical analyses were carried out in the R programming environment [58]. The selected results are illustrated by a mosaic display-a graphical method developed by [61]. In a mosaic display, each of the cell counts of the contingency table is represented by a tile proportional to the cell frequencies. The relative size of a tile becomes an indicator for whether the observed data deviate from the hypothesised mode [62].

\subsubsection{Analysis of External Factors Influencing the Amount of Berries Collected in the $C Z$}

Provided that the total amount of forest berries collected in a given year is affected by the natural conditions, a multi-regression model (5) was used to analyse the total amount of the collected berries, where $\mathrm{y}$ is the annual amount of the collected berries and $x_{1}, x_{2}, \ldots, x_{k}$ are the explanatory variables reflecting the natural conditions, such as the precipitation and temperature and $\beta 1, \beta 2, \ldots, \beta \kappa$ are the regression coefficients.

$$
y=\beta_{0}+\sum_{i=1}^{k} \beta_{i} x_{i}
$$

In our case, the average temperatures and precipitation in the relevant months during the period of 1994-2018 and the annual amount of salvage felling are used as independent variables. The selection of the relevant months tested in the linear model: April, May, June, July is based on [63], who states that the climatic factors before the flowering season had no significant effect on the yields of the bilberries. A longer time series was used, including the period of 1994-2007, when the estimation of the total harvested amount of forest berries was undertaken by using the same methods as in the period of 2008-2018. (As mentioned above, the personal characteristics of the berry pickers had regrettably not been collected in the period of 1994-2007.) The data on the precipitation and temperatures were obtained from the Czech hydrometeorological institute [64]. To select the most important variables in the model, the method described in [65] was used. First, the potential explanatory variables $x_{1}, x_{2}, \ldots$, $x_{k}$ are defined. By combining these explanatory variables, all the possible models can be created $\left(2^{k}\right.$ models can be created from the k variables), one can evaluate them by a certain criterion and select the best model. In our case, the Akaike information criterion (AIC) is used for the evaluation of the models in the way detailed in [66]. The AIC estimates the relative amount of information lost by a given model, i.e., the smaller the AIC value, the more suitable the model is. Specifically, consider a set of $m$ models and denote $\mathrm{AIC}_{\text {min }}$ as the smallest value from their corresponding Akaike information criterions. Then, the expression $\exp \left(\left(A I C_{\min }-A I C_{i}\right) / 2\right)$ can be interpreted as being proportional to the probability that the $i$-th model minimises the information loss. In our case, when $\mathrm{k}=9$ (9 variables are used), the total number of linear models equals $2^{9}$, i.e., 512.

The most relevant models are ordered according to the AIC. Each model is supplemented by the determination coefficient (R2) and the statistical significance of the model as a whole ( $p$-value). The calculation was performed by the supplementary functions package MuMIn of the R program [58].

\section{Results}

\subsection{Basic Data on Socio-Economic Importance}

Figure 1 shows the variation in the total amount of collected berries. For example, in 2008, an extremely low forest berry harvest is evident. In addition to explaining the influence of the climatic factors (precipitation and temperature), which are analysed below in the linear model of Section 3.4. (in 2008, the precipitation was low-90\% compared to the long-term average, moreover, in May and June, it was only $83 \%$ and $75 \%$ of the average, respectively), another important factor was the fact that, in mid-January 2007 and at the turn of February and March 2008, two extremely strong windstorms: 
Kyrill and Emma hit most of the Central European countries [67] including the CZ. It can be reasonably assumed that the consequences of the storms and the ongoing and subsequent felling reduced the public attendance in the forests. This is also the reason why the annual amount of salvage felling is used as one of the independent variables in the linear model (5). Salvage felling is the practice of felling trees in forests that have been damaged by wildfire, insect infestation, or other natural disturbances. On the other hand, in 2013, there was an extraordinary volume of forest fruits, especially bilberries. That year, in June, the above-average precipitation (variable X3 was $164 \%$ of the long-term average of 1981-2010, and, in July, the above-average temperatures (variable X8) were $120 \%$ of the long-term average of 1981-2010. This apparently had a positive effect on the bilberry production.

In the $\mathrm{CZ}$, there are not any official data about the prices of forest berries tracked by the Czech Statistical Office; berries are not included into the $\mathrm{CZ}$ consumer basket. Therefore, the estimation of the value of the collected berries is undertaken by multiplying the total amount of the collected berries and the average price of the forest berries found in a survey in 2018 (Table 3).

Table 3. The estimate of the amounts of the average annual collection and annual value of the four species berries in millions of EUR at the 2018 prices (ČNB, 2020).

\begin{tabular}{ccccc}
\hline & Bilberries & Cowberries & Raspberries & Blackberries \\
\hline Average annual share of respondents collecting berries & $38.73 \%$ & $6.35 \%$ & $28.09 \%$ & $24.43 \%$ \\
Average annual amount collected in million kg & 8.9 & 0.7 & 2.9 & 1.9 \\
The average price per kg in EUR in 2018 & 5.7 & 6.7 & 6.4 & 18.9 \\
Estimate of the average annual value of harvested & 50.7 & 4.8 & 12.5 \\
berries in prices at 2018 (million EUR) & & &
\end{tabular}

For comparison, due to the bark beetle calamity and the collapse of wood prices, the state support for private forest owners was as high as EUR 100 million (it is expected to be paid in 2019 and 2020) [68], thus, an average of EUR 50 million per year, which is equal to the estimated annual value of the harvested bilberries. Although forest berry collecting is important for a large part of the population, due to the free access to the forest and the uncontrolled harvesting of the forest berries, it is of no economic importance to the forest owners as of yet.

\subsection{Differences in the Income from the Forest Fruits among the Respondents}

For studying how the amount of the collected forest berries are distributed among the respondents, the Gini coefficient (1) was calculated for each year of the period of 2008-2018. Only the respondents who collected bilberries are considered. The disparity among the berry pickers is, in some years, even far more significant and relates to all the kinds of collected forest berries. This fact is documented in Table 4, which shows the unequal collection of all the individual species of the forest fruits that reaches high values in some years.

Table 4. The values of the Gini coefficients for the period of 2008-2018.

\begin{tabular}{ccccc}
\hline Year & Bilberries & Cowberries & Raspberries & Blackberries \\
\hline 2008 & 0.566 & 0.605 & 0.621 & 0.568 \\
2009 & 0.716 & 0.515 & 0.639 & 0.663 \\
2010 & 0.767 & 0.502 & 0.612 & 0.629 \\
2011 & 0.827 & 0.826 & 0.744 & 0.789 \\
2012 & 0.769 & 0.659 & 0.827 & 0.849 \\
2013 & 0.868 & 0.637 & 0.698 & 0.712 \\
2014 & 0.728 & 0.673 & 0.629 & 0.579 \\
2015 & 0.772 & 0.676 & 0.700 & 0.698 \\
2016 & 0.859 & 0.803 & 0.734 & 0.820 \\
2017 & 0.675 & 0.584 & 0.634 & 0.714 \\
2018 & 0.642 & 0.510 & 0.520 & 0.496 \\
\hline
\end{tabular}


A more detailed analysis of the distribution of these inequalities in the bilberry harvest is provided by the Lorenz curve (2). The cumulative volume of the collected amount of bilberries each year for the period of 2008-2018 is placed on the y axis (first ordered in ascending order) and the cumulative percentage of the respondents is placed on the $x$ axis.

Figure 3 shows the unevenness of the bilberry collection, when, according to Pareto's rule, 20\% of the respondents collect more than $80 \%$ of the collected amount. Analysing the concentration curve, it can be seen that a relatively very small portion of the collecting respondents (less than $10 \%$ ) gains more than $50 \%$ of the total value of the collected bilberries (in 2013, it was more than $80 \%$ ). An explanation for the extreme value of 0.868 for the bilberries in 2013 may be that the favourable climatic conditions resulted in an extremely abundant bilberry crop-the total amount collected was $13.4 \mathrm{million} \mathrm{kg}$ (Figure 1), as compared to the long-term average of 8.97 million $\mathrm{kg}$ (Table 3). Some respondents participated in the very intensive collection either for commercial or personal reasons-they took a holiday to collect bilberries when it was worth it. If we calculate this portion to all the households in the $\mathrm{CZ}$ (the collecting households represent about $38 \%$ of all the households), it is evident that less than $4 \%$ of the population gain more than $50 \%$ of the total value of the forest berries. There are several aspects connected with these results:

- Biological factors: The very intensive collection in over-visited areas in the densely populated Central Bohemia, including the method of harvesting (some harvesters even pluck whole plants from the ground and then pluck the berries), has a very negative impact on the quality and sustainability of the forest berry production. On top of that, the most suitable localities for bilberry picking are situated in protected nature areas (national parks and protected landscape areas), where, in addition to the damage to the stands of bilberry bushes themselves, the increased attendance may pose a problem in disturbing the animals living there [69]. For instance, in the Krkonoše National Park, its administration in the years 2000-2017 (e.g., [70]—the so-called "bilberry decree") restricted access to selected localities mainly due to the excessive collection of bilberries and the related negative impacts. However, an analysis of the administration has shown that this over-collection has increasingly become a smaller and smaller problem over time, which is why the restriction has been lifted since 2018 [71].

- Legal aspects: Ownership rights to the forests, including the possibility of restricting others' access to the forests and exclusion rights, vary widely across Europe [72]. In the CZ, the "everyman's right" applies, i.e., free entry into the forest and the collection of berries is possible. The exact wording of the Czech Forest Act is as follows: "Every individual shall be entitled to enter the forest at their own risk, and to collect any forest products and dry brushwood lying on the ground for their own needs. While doing so, they shall be obliged not to damage the forest, not to interfere with the forest environment and to follow the instructions of the owner or tenant of the forest and their staff." The question is, if the Act also allows the collection of berries for commercial purpose or not. It speaks about the collection for one's own needs, not about one's self-consumption. The problem is in the terms in the Czech language also-the word "potřeba" utilised in the Forest Act can be translated as need (or use), but in fact there should have been the word "spotřeba" translated and understood in an economic sense as consumption. This shortcoming of the law is known, but there is no political will to change the law for one letter. If the word "spotřeba" (consumption) was used, then it would be clear that commercial picking of berries is not possible; in the current situation, i.e., when using the word "potřeba" (need), the interpretation (even legally) is unclear. Collecting for commercial purposes is, therefore, not explicitly prohibited, and the term "own needs" is not defined in terms of quantity. It is forbidden, however, to collect forest fruits in a way that damages the forest.

- $\quad$ Economic and ethical aspects: Official commercial picking does not exist in the CZ, therefore, it is not possible to analyse the amount. Based on informal telephone interviews with domestic forest berry processors, it was found that the processors mainly import raw materials from Ukraine and Poland. From this, it can be deduced that most berries picked in the Czech Republic are sold 
either on the domestic market by direct sales "by the road" (to a lesser extent), or in Germany and Austria on "farmers' markets". It was similarly argued in [73] that non-timber forest products (NTFP) entrepreneurs mainly create distant markets, e.g., not connected with the picking locality. Such a collection type and the following transfer could be described as "organised berry picking". The sale takes place on a grey market, which brings untaxed income only for a small group (collection organisers), which is not related to the forest owners. Moreover, this is occurring in situations when many forest owners are losing money or losing most of the value of the forest property due to the bark beetle calamity and the rapid decrease in the coniferous wood prices from 2017 [74-76].

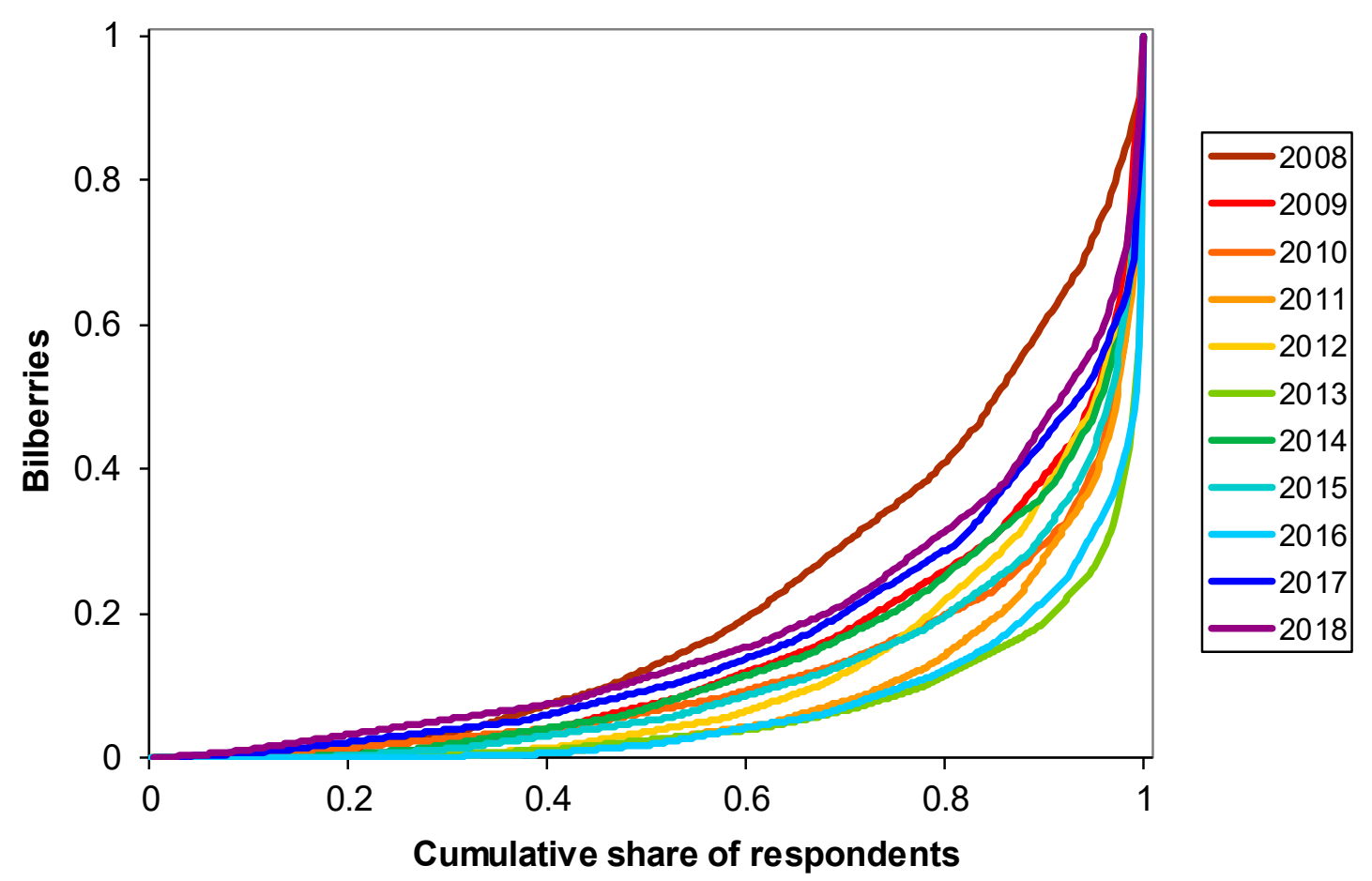

Figure 3. Lorenz curve applied to the bilberry collection.

\subsection{Relationship Analysis}

A preliminary analysis can be performed by descriptive statistics methods. Mosaic displays are a suitable method for the graphical presentation of contingency tables. The figures below show the selected results, namely, the relationships between the collection of the bilberries and explaining the variables of sex, age, size of residence and region.

The hypothesised model is based on the independency of the variables. It means that, i.e., the cells in the same row should have the same height regardless of the explanatory variable.

The first analysed contingency table is constructed by using the categorical variable of the respondent's gender and the categorical variable of the amount of bilberries collected. Using a mosaic display (see Figure 4), it can be seen that the proportion of men not collecting bilberries (category 0 on the $y$ axis) is much higher than in the case of women. The significance of the differences can be evaluated by Fisher's exact test [49]. In this case, the resulting $p$-value of 0.0005 indicates highly significant differences.

If the age category is analysed (Figure 5), it is evident that the category of non-pickers is higher in older people (71+) and seniors (56-70), the percentage of "occasional pickers" (the category $0.01-2 \mathrm{~kg}$ ) is highest in the age category of 26-55 years and in the category of 15-25. 


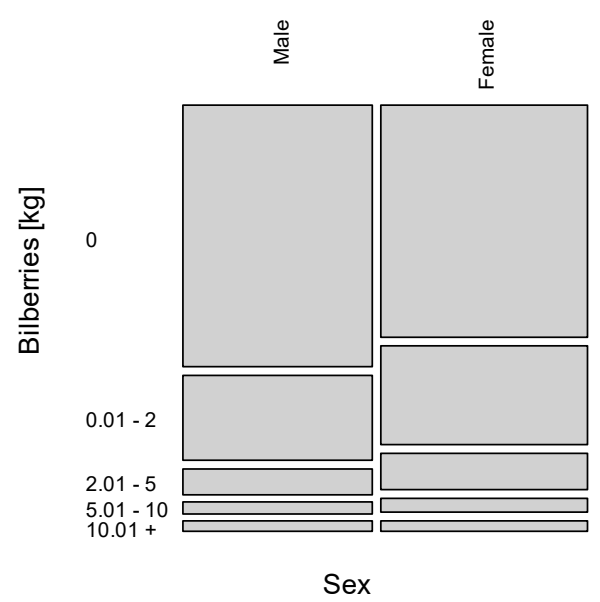

Figure 4. The mosaic display of the relationship between the gender of the respondent and the amount $(\mathrm{kg})$ of bilberries collected.

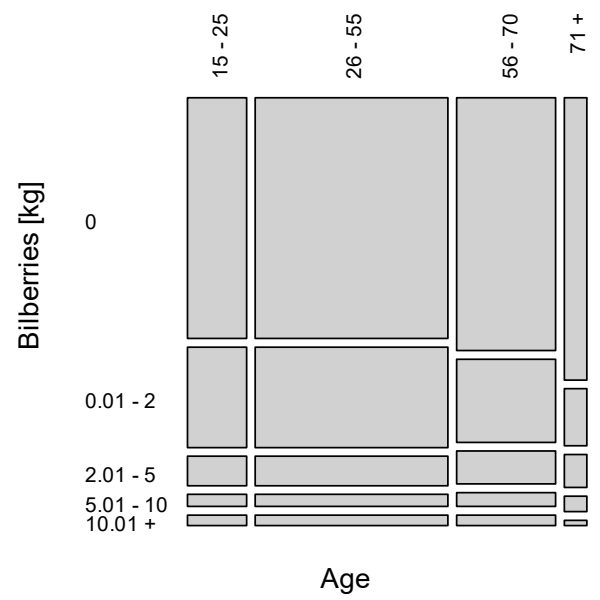

Figure 5. The mosaic display of the relationship between the age of the respondent and the amount $(\mathrm{kg})$ of bilberries collected.

Figure 6 shows that the category of non-pickers (category 0 on the y axis) is lower in villages and small towns (up to 4999 inhabitants). However, the category of non-pickers has a surprisingly lower representation in cities over 100,000 inhabitants, whose residents are more likely to compensate for a city life by spending their free time outdoors and on holiday. City dwellers often own weekend houses and cottages in the countryside, which they often commute to. Czech people are "cottage people"; there are 287,000 cottages in the country, and it is said that every fifth Czech house is used for recreational purposes. Only more cottages per inhabitants can be found in Sweden [77]. Cottages are a part of the so-called second housing, which also is included in the work of [78] and [79]. The outdoor stay of these people is often accompanied by a forest visit and "recreational" forest berry collection. These results are consistent with Šišák [41], [80]. Accordingly, Figure 7, where the size of the collection is analysed compared to the three regions: PC (the capital Prague and Central Bohemia), B (the rest of Bohemia), M (Moravia). Again, it is obvious that the Central Bohemia area, with a large number of recreational facilities and large cities, where the inhabitants of Prague are a significant portion of the visitors, which lies in the centre of this area, shows a higher collection intensity than, e.g., Moravia. In the case of Central Bohemia, the number of forest visitors is so high (mostly because of the visitors from Prague, who leave the area of the capital city to go into "nature") that the volume of forest fruit harvesting approaches the limits of the forest production possibilities. 


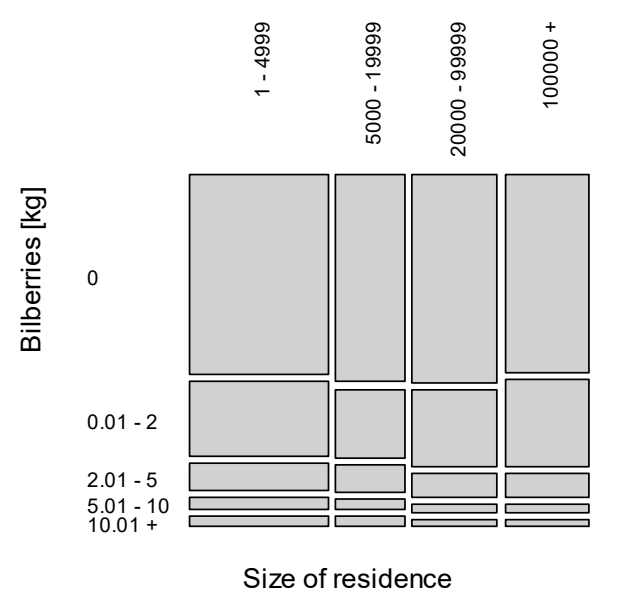

Figure 6. The mosaic display of the relationship between the size of the residence and the amount $(\mathrm{kg})$ of bilberries collected.

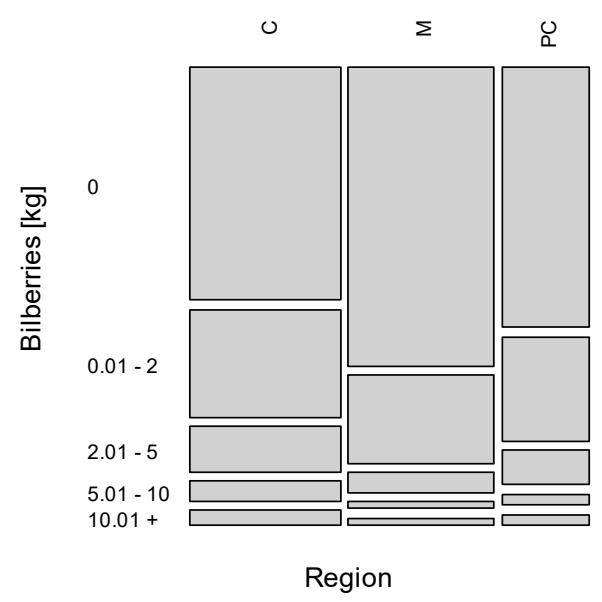

Figure 7. The mosaic display of the relationship between the region of the respondent and the amount $(\mathrm{kg})$ of bilberries collected.

Very intensive collectors (a collected volume of more than $10 \mathrm{~kg}$ per year) can mainly be found among women (in the non-central areas of Bohemia) in municipalities with less than 5000 inhabitants. These collectors collect rather close to their place of residence.

The analyses show that women under the age of 55 living in larger cities (100,000 inhabitants) in Bohemia (region PC or region B) are a suitable target group in terms of marketing programmes. These frequent weekend visitors and occasional berry pickers are the most mobile and their flow can be more easily redirected. These people can be the goal of relatively effective and inexpensive explanatory campaigns drawing attention to preventing inappropriate collection methods or to reducing excessive forest attendance in some places.

Mosaic displays are illustrative, but they capture the relationship of only two quantities. In reality, quantities such as the amount of collected berries may be affected by the interaction of many different factors. Their relationship can be evaluated by a proportional odds model.

Table 5 shows the standardised outputs from the polr function, as mentioned in the methodological section, supplemented by the $\mathrm{p}$ values obtained from the function calculation (4). If the $p$-value is less than 0.05 (the difference from the reference category which is considered statistically significant), the values are shown in bold letters. Within a given variable, the other levels of the variable are calculated relative to the first category of the variable (i.e., in the case of the age, 15 to 25 years). So, the categories in the first row of Table 2 are used as a reference to the implicit value equal to 0 . That is why they are not displayed in Table 5. See, e.g., [81]. 
Table 5. The characteristics of the respondents explaining the volume of the collected amount.

\begin{tabular}{|c|c|c|c|c|c|c|c|c|}
\hline & \multicolumn{2}{|c|}{ Bilberries } & \multicolumn{2}{|c|}{ Cowberries } & \multicolumn{2}{|c|}{ Raspberries } & \multicolumn{2}{|c|}{ Blackberries } \\
\hline & b & $p$-Value & $\mathbf{b}$ & $p$-Value & B & $p$-Value & $\mathbf{b}$ & $p$-Value \\
\hline Age $26-55$ & -0.056 & 0.321 & 0.690 & $<0.001$ & 0.026 & 0.673 & -0.053 & 0.416 \\
\hline Age $56-70$ & -0.143 & 0.022 & 0.633 & $<0.001$ & -0.163 & 0.019 & -0.171 & 0.018 \\
\hline Age 71+ & -0.463 & $<0.001$ & 0.436 & 0.055 & -0.315 & 0.004 & -0.368 & 0.002 \\
\hline Sex female & 0.328 & $<0.001$ & 0.217 & 0.010 & 0.284 & $<0.001$ & 0.266 & $<0.001$ \\
\hline Education 2 & 0.109 & 0.012 & -0.009 & 0.925 & 0.141 & 0.003 & 0.172 & $<0.001$ \\
\hline Education 3 & 0.173 & 0.003 & 0.273 & 0.019 & 0.156 & 0.016 & 0.190 & 0.005 \\
\hline Size of res. 2 & -0.146 & 0.010 & -0.298 & 0.014 & -0.149 & 0.019 & -0.119 & 0.076 \\
\hline Size of res. 3 & -0.154 & 0.003 & -0.246 & 0.032 & 0.026 & 0.647 & 0.038 & 0.537 \\
\hline Size of res. 4 & 0.066 & 0.235 & 0.146 & 0.221 & 0.133 & 0.029 & 0.155 & 0.015 \\
\hline Region M & -0.768 & $<0.001$ & -1.434 & $<0.001$ & -0.017 & 0.734 & 0.102 & 0.053 \\
\hline Region PC & -0.400 & $<0.001$ & -0.514 & $<0.001$ & 0.114 & 0.065 & 0.072 & 0.276 \\
\hline Proportional Odds Score test & 134.167 & $<0.001$ & 44.549 & 0.086 & 59.288 & 0.003 & 48.649 & 0.039 \\
\hline
\end{tabular}

Table 5 shows a significant age effect for the volume of the collected bilberries. Namely, there are significant differences between the reference age category of 15-25 years and the categories of 56-70 years $(p$-value $=0.022)$ and $71+$ years $(p$-value $<0.001)$. However, there is not any significant difference between the categories of $15-25$ and 26-55 years, so the level 26-55 is not bold (also compared with Figure 5).

The $b$ coefficients (estimations of the $\beta$ regression coefficients) are negative in both cases; this means that the respondents in the age categories of 55-70 and 71+ show a tendency to collect a lower volume of bilberries. There is also a significant difference between genders, where females tend to collect a larger volume of bilberries than males ( $p$-value $<0.001$ ). The effect of age and sex on the collected amount of raspberries and blackberries is similar to that on the collection of bilberries (positive $b$ coefficients in the corresponding cells). For cowberries, the age categories $26-55$ and 56-70 predominate. People with a high education use the visit to the forest to occasionally harvest all forest berries (positive and relatively small $\mathrm{b}$ coefficients in the Education 3 line). Residents of smaller towns (size of res. 2: 5000-19,999) collect less bilberries, cowberries and raspberries (negative male b coefficients for size of res. 2). Residents of central Bohemia (PC region) and especially Moravia (region M) collect less bilberries and cowberries than the rest of the country (non-central areas of Bohemia-region B)-a negative value of $b$ in the corresponding cells. We can similarly interpret the rest of Table 5.

\subsection{Natural Factors-Application of the Linear Regression Model}

To explain the changes in the collected amount, a multilinear regression model was used with explanatory variables: the average temperature and the average precipitation in the months of April, May, June and, July and the annual salvage felling (see Table 6). The climatic data in the Czech Republic were selected. The annual amount of collected bilberries in the CZ (see Figure 1) was chosen as the independent variable $y$ in the linear model Equation (4). The temperatures and precipitations in the relevant months and the amount of salvage felling, see Table 6, were chosen as the explanatory variables reflecting the natural factors. For technical reasons (the length of the time series is 25 years), the number of explanatory variables in the model (1) must be limited. Each variable is a vector with 25 components, each of which corresponds to the values observed in each single year of the 25-year period of 1994-2018. 
Table 6. The basic set of the nine explanatory variables used in the multilinear regression model (5).

\begin{tabular}{ccccc}
\hline & \multicolumn{4}{c}{ Time Period-Month } \\
\hline & April & May & June & July \\
\hline Average precipitation in $\mathrm{mm}$ & $\mathrm{X} 1$ & $\mathrm{x} 2$ & $\mathrm{X3}$ & $\mathrm{X} 4$ \\
Average temperature in ${ }^{\circ} \mathrm{C}$ & $\mathrm{X} 5$ & $\mathrm{X} 6$ & X7 & X8 \\
\hline \multirow{3}{*}{ Annual salvage felling in mil. $\mathrm{m}^{3}$} & \multicolumn{4}{c}{ Time Period-Whole Year } \\
\hline
\end{tabular}

In Table 7, the top 10 most relevant models are shown ranked according to the Akaike information criterion (AIC). In most models, we can observe a statistically significant positive correlation in the collected amount with the average monthly precipitation in June (X3) and a positive correlation in the collected amount with the average monthly temperature in July (X8) when the bilberries ripen. This result is consistent with the study of [82], which states that berry crops are influenced by the weather conditions during the berry ripening period.

Table 7. The model selection table—-the variables (precipitation, temperature, salvage felling) explaining the volume of the collected amount of bilberries.

\begin{tabular}{|c|c|c|c|c|c|c|c|c|c|c|c|c|}
\hline Intercept & $\mathrm{X} 1$ & $\mathrm{X} 2$ & $\mathrm{X} 3$ & $X 4$ & X5 & $\mathrm{X} 6$ & $\mathrm{X} 7$ & $\mathrm{X} 8$ & X9 & AIC & R2 & $p$-Value \\
\hline-5.446 & & & 0.042 & & & & & 0.675 & -0.180 & 115.2 & 0.405 & 0.011 \\
\hline-3.867 & & & 0.047 & & & & & 0.498 & & 115.6 & 0.313 & 0.016 \\
\hline 5.440 & & & 0.045 & & & & & & & 116.0 & 0.218 & 0.019 \\
\hline 14.870 & & & 0.035 & & & & -0.522 & & & 117.0 & 0.272 & 0.030 \\
\hline 5.187 & & & 0.037 & & & & -0.477 & 0.474 & & 117.1 & 0.358 & 0.023 \\
\hline 11.360 & & & 0.041 & & & -0.423 & & & & 117.4 & 0.261 & 0.036 \\
\hline-1.457 & & & 0.048 & & -0.265 & & & 0.483 & & 117.5 & 0.348 & 0.027 \\
\hline 7.740 & & & 0.047 & & -0.286 & & & & & 117.5 & 0.259 & 0.037 \\
\hline 6.886 & & & 0.041 & -0.013 & & & & & & 117.5 & 0.258 & 0.038 \\
\hline 9.648 & & & 0.034 & -0.022 & & & & & -0.182 & 117.6 & 0.345 & 0.028 \\
\hline
\end{tabular}

The AIC score shows a significant negative correlation with the annual salvage felling, which is also noticeable ( $p$-value 0.011). Salvage felling may have an impact on both the production of the forest berries and the willingness of the berry pickers to visit the forest. Due to the continuing bark beetle calamity and salvage felling, it can be expected that this factor will play an increasingly important role in the future. In some areas, due to the ongoing felling, people have reduced the intensity of the visits to the forest. In 2016, the total amount of harvested timber amounted up to 16 million cubic metres (less than 60\% was represented by salvage felling). In 2018, it was 25 million cubic metres, of which $90 \%$ of the wood was harvested due to salvage felling [39,50]. The amount of logged wood is still increasing. In many places where salvage felling has already occurred, the natural conditions are likely to change, and the occurrence of bilberries may be reduced. According to [83], with reference to [84], this exact occurrence happened in Finland, where the bilberry cover decreased due to the intensive forest management.

The other models show a negative correlation with the temperatures in April, in May or in June (variables X5, X6, X7). The influence of a hot spring does not seem to be favourable. The last two models show a negative influence with the precipitation in July, which can be interpreted as that a rainy July prevents the berry pickers from visiting the forest as these factors significantly affect the expected volume of the harvesting, production size and forest attendance, they need to be considered when planning changes in forest management aimed at the potential development of "bilberry management".

\section{Discussion and Conclusions}

The most important NWFPs in the CZ are mushrooms and forest berries. However, unlike berries, mushrooms have been observed as one category from the very beginning of the research, 
without distinguishing the species (many respondents are not able to name the species correctly). Thus, the results of the annual research on mushrooms cannot be linked to a specific growing season or to a specific management measure concerning the forest. This article, therefore, analysed the significant factors influencing the amount of collected forest berries in the CZ. The analysis has been carried out using four research questions. The answers to them are as follows.

RQ 1. Using a concentration curve and the Gini coefficient, the very uneven distribution of the picked amount of berries among the berry pickers has been proven.

RQ 2. A detailed statistical testing analysed and proved the significance of the demographic and geographic factors of the berry pickers: based on their age, sex, education, size of residence and region, where the picker lives. This analysis has been carried out for each generally picked type of berry, i.e., bilberries, cowberries, raspberries and blackberries. The dependence on the amount of the collected forest berries was demonstrated for all the analysed categorical variables to a greater or lesser extent, e.g., women (in non-central areas of Bohemia) in municipalities with less than 5000 inhabitants are mainly found to be very intensive collectors (a collected volume of more than $10 \mathrm{~kg}$ per year).

RQ 3. The data obtained over the 25 years of observation indicate a significant variation in the total amount of the forest berries collected, which is also confirmed by the values of the coefficient of variation calculated in Table 1, as values around 30\% prove the considerable variability in the analysed data, see [47].

It was possible to perform more detailed analyses of the external factors influencing this variation for bilberries as the most frequently collected forest berry, for which the largest amount of the data is available.

RQ 4. The average temperatures and precipitation in the relevant months and the total volume of the incidental felling in the given year were used as explanatory variables for the external factors. When testing a number of linear regression models, the precipitation in June and the temperature in July proved to be the most important variables.

Based on the above analyses, it is, to some extent, possible to characterise the potential customer (forest berry pickers). Analyses of this type are of great importance for the future application of marketing methods in the development of territorial marketing, in the understanding of the structure of the demand, and, thus, in which direction to orient the supply NWFP as one of the outputs of the forest ecosystem management.

The social significance of our analyses lies in the fact that, due to its popularity, the occasional harvest of forest berries has become an integral part of the recreational use of the forest for the Czech population. A similar conclusion is reached, for example, by [85] on a Finish case. The researchers [86] use the term "multi-objective forest planning" for the approach where several forest outputs and services are considered simultaneously. Promoting the intentional cultivation and production of forest berries in order to make better use of the natural resources, forest land and forests, the diversification of the forestry income needs to be further envisaged. Numerical models are needed to predict the development of different ecosystem services (including berry yields) along with the forest development [87]. The need to model both the timber production as well as the bilberry production is also emphasised by [88].

The current bark beetle calamity in Central Europe is forcing forest owners to reconsider their current forest management policies. As part of the creation of new forest plans, they can also incorporate more production and, subsequently, the NWFP offer. It is logical that the form of ownership and management goals will play a role here. The state, and especially municipalities, as forest owners, can be expected to be very interested in the rural development, including the support of tourism, to choose a form of management that is friendly to forest visitors, including "collectors". The research [18] considers the optimisation of the wood and berry production as being the most meaningful in public forests. The economic goals of private forest owners may be different [89], an increasing number of those who do not own a forest for economic gain [90] and can, therefore, be motivated to manage forest as public forests. To date, the largest group of private owners-focused on forest profits-still does not 
have such a motivation. Although, as our results show, the economic potential of harvesting bilberries and other forest berries is great, it only remains theoretical for owners, due to the legal restriction of property rights in the CZ related to the owner's ability to restrict entry and the free harvest of forest fruits by the public in his or her woods [71]. There is an ongoing debate about the possible solutions in the Czech Republic. There are several theoretical possibilities on how to solve this issue, divided according to the degree of the legislative changes and government interventions. The utilisation of non-fundamental changes (e.g., changes within the traditional arrangement) is more realistic in the CZ. Such slight changes potentially could be of a broad scope: from direct government intervention in timber prices, to small changes in the legislation on the forest berries collection, including the definition of the term "one's own needs" in the sense of "one's own consumption". This issue has already been addressed in other research activities [91]. Similar problems with the commercial picking occur in other countries, e.g., according to [15], Latvia is currently the biggest wild bilberry exporter in Europe. While the sector has grown in recent years, the Latvian government's involvement in regulating it has remained very limited. The utilisation of fundamental changes is unlikely in the Czech Republic. The fundamental changes are considered to be those, thanks to which, where it would be possible to carry out the internalisation of the positive externalities (e.g., on the forest harvesting effects). Such changes are not easy to achieve because they interfere with the belief system of the public (due to the historically used everyman's right system). Such changes may include, for example, the possibility of giving the forest owner the opportunity to charge the public (pickers) for the collection of berries by an amount - a flat rate or for a quantity, and, thus, allow the diversification of the forest owners' income. Such examples are applied, e.g., in the USA [92], Spain [93], Finland [94] or Italy [95]. As mentioned by [96], countries like Italy, France and Spain were among the first to regulate the harvesting rights of wild forest products (WFPs) due mainly to the high anthropic pressure on the WFP resources and consequent depletion due to overharvesting. The harvesting regulation mainly focuses on the promotion of the best harvesting practices and commercialisation rules. The authors of this study [96] emphasised that among all the topics related to the WFP policies, this last part is probably the most debated due to specificities of each area, the species collected and cultural uses; moreover, almost no countries have properly coordinated harvesting rules with their fiscal laws, triggering conflicts between policy makers and wild forest products commercial users.

Thanks to the everyman's right, the prevailing public opinion is that forest ecosystem services are non-tradable public goods. The mentioned types of changes correspond to [97] the theoretical approach, according to which, a higher integration into the market mechanism can be achieved, in practice, in two ways. The first one uses the fact that the degree of rivalry increases, for example, through a significant increase in the demand, and the public good then becomes a collective good. In such a situation, users already compete with each other (e.g., when utilising popular "picker" areas). The second way is a strategy to achieve exclusion, for example, through changes in the legal framework (access rights) or through the enforcement of property rights (e.g., by fencing off the area, entry control together with the payment of entry fees). As long as the customer does not compete, the good is considered a club good; with a growing degree of rivalry, it becomes a private good.

The full internalisation (e.g., privatisation) is but a very sensitive issue, because such privatisation of wild products has had a negative effect on the market, with an increment in the production costs of wild resources, while only a negligible income for the forest owner was achieved [98]. Although the ownership rights of private forest owners are being slightly strengthened, even in the CZ [99], they have not reached the possibilities of other states (e.g., Spain, France or Italy). In these countries, it is possible to find examples of good practices involving the internalisation of positive externalities, in particular, in the form of charging for the collection of forest crops or, at least, the determination of the maximum amount collected. Due to the long-term drought followed by the bark beetle calamity, there is a large surplus of spruce wood on the European market, which is the main economic tree species in the CZ. Its price has fallen sharply, and, at the same time, the area is growing rapidly, which, in the next few decades, was supposed to be the main economic source for the private forest owners. 
However, due to the infestation with the spruce bark beetle, it will have almost no economic effect in the foreseeable future. The economically oriented forest owner is, thus, faced with the decision of how to manage these areas in the future. If it were possible (a political effort) to implement at least some of the above-mentioned non-fundamental measures, the practical possibility on how to solve the economic aspect comes into play. Then the forest owner should have the opportunity to incorporate the issue (and therefore also the income) of forest berries into forest management (see, e.g., [100-102]). The Association of Forest Owners has a relatively strong negotiating position in the CZ [103] and can try to move the debate and political negotiations aimed at increasing their exclusion rights [104] or reducing the amount of forest crop collection. Focusing their management on the "bilberry" management can, thus, be a potential compensation for the expected losses.

Author Contributions: Conceptualisation, M.R. and V.J.; methodology, M.R. and L.Š.; software, D.Z.; writing-original draft preparation M.R., V.J., P.P., R.D. and J.M.; writing-review and editing, D.Z., L.Š., M.R., P.P., R.D. and L.Š. All authors have read and agreed to the published version of the manuscript.

Funding: This work was supported by the National Agency for Agricultural Research of the Czech Republic (NAZV projects no. QK1920272 and No. QK1820041) and EVA4.0 (grant no. CZ.02.1.01/0.0/0.0/16_019/0000803) financed by Operational Programme Research, Development and Education.

Conflicts of Interest: The authors declare no conflict of interest.

\section{References}

1. Berkes, F.; Davidson-Hunt, I.J. Biodiversity, traditional management systems, and cultural landscapes: Examples from the boreal forest of Canada. Int. Soc. Sci. J. 2006, 58, 35-47. [CrossRef]

2. Chopra, K.; Kumar, P. Forest biodiversity and timber extraction: An analysis of the interaction of market and non-market mechanisms. Ecol. Econ. 2004, 49, 135-148. [CrossRef]

3. Costanza, R.; De Groot, R.; Sutton, P.; Van Der Ploeg, S.; Anderson, S.J.; Kubiszewski, I.; Farber, S.; Turner, R.K. Changes in the global value of ecosystem services. Glob. Environ. Chang. 2014, 26, 152-158. [CrossRef]

4. Jenkins, M.; Schaap, B. Forest Ecosystem Services. Background Analytical Study 1. United Nations Forum on Forests. 2018. Available online: https://www.un.org/esa/forests/wp-content/uploads/2018/05/UNFF13_B kgdStudy_ForestsEcoServices.pdf (accessed on 15 September 2019).

5. Cai, M.; Pettenella, D.; Vidale, E. Income generation from wild mushrooms in marginal rural areas. For. Policy Econ. 2011, 13, 221-226. [CrossRef]

6. Croitoru, L. Valuing the non-timber forest products in the Mediterranean region. Ecol. Econ. 2007, 63, 768-775. [CrossRef]

7. De Aragón, J.M.; Riera, P.; Giergiczny, M.; Colinas, C. Value of wild mushrooms picking as an environmental service. For. Policy Econ. 2011, 13, 419-424. [CrossRef]

8. Merlo, M.; Croitoru, L. (Eds.) Valuing Mediterranean Forests: Towards Total Economic Value; CABI International: Wallingford, UK; Cambridge, MA, USA, 2005; p. 406.

9. Pettenella, D.; Secco, L. Small-scale forestry in the Italian Alps: From mass market to territorial marketing. In Small-Scale Forestry and Rural Development: The Intersection of Ecosystems, Economics and Society, Proceedings of IUFRO 3.08 Conference, Galway, Ireland, 18-23 June 2006; Wall, S., Ed.; Galway-Mayo Institute of Technology: Galway, Ireland, 2006; pp. 398-408.

10. Živojinovic, I.; Nedeljković, J.; Stojanovski, V.; Japelj, A.; Nonić, D.; Weiss, G.; Ludvig, A. Non-timber forest products in transition economies: Innovation cases in selected SEE countries. For. Policy Econ. 2017, 81, 18-29. [CrossRef]

11. Schunko, C.; Lechthaler, S.; Vogl, C.R. Conceptualising the Factors that Influence the Commercialisation of Non-Timber Forest Products: The Case of Wild Plant Gathering by Organic Herb Farmers in South Tyrol (Italy). Sustainability 2019, 11, 2028. [CrossRef]

12. Turtiainen, M.; Nuutinen, T. Evaluation of Information on Wild Berry and Mushroom Markets in European Countries. Small-Scale For. 2011, 11, 131-145. [CrossRef]

13. Karjalainen, E.; Sarjala, T.; Raitio, H. Promoting human health through forests: Overview and major challenges. Environ. Heal. Prev. Med. 2009, 15, 1-8. [CrossRef] 
14. Knekt, P.; Kumpulainen, J.; Järvinen, R.; Rissanen, H.; Heliövaara, M.; Reunanen, A.; Hakulinen, T.; Aromaa, A. Flavonoid intake and risk of chronic diseases. Am. J. Clin. Nutr. 2002, 76, 560-568. [CrossRef] [PubMed]

15. Grivins, M. A comparative study of the legal and grey wild product supply chains. J. Rural. Stud. 2016, 45, 66-75. [CrossRef]

16. Kalt, W.; Cassidy, A.; Howard, L.R.; Krikorian, R.; Stull, A.J.; Tremblay, F.; Zamora-Ros, R. Recent Research on the Health Benefits of Blueberries and Their Anthocyanins. Adv. Nutr. 2020, 11, 224-236. [CrossRef] [PubMed]

17. Lovrić, M.; Da Re, R.; Vidale, E.; Prokofieva, I.; Wong, J.; Pettenella, D.; Verkerk, P.J.; Mavsar, R. Non-wood forest products in Europe-A quantitative overview. For. Policy Econ. 2020, 116, 102175. [CrossRef]

18. Miina, J.; Pukkala, T.; Kurttila, M. Optimal multi-product management of stands producing timber and wild berries. Eur. J. For. Res. 2016, 135, 781-794. [CrossRef]

19. Matilainen, A.; Lähdesmäki, M. Nature-based tourism in private forests: Stakeholder management balancing the interests of entrepreneurs and forest owners? J. Rural. Stud. 2014, 35, 70-77. [CrossRef]

20. Hansen, K.; Malmaeus, M. Ecosystem services in Swedish forests. Scand. J. For. Res. 2016, 31, 626-640. [CrossRef]

21. Saarikoski, H.; Jax, K.; Harrison, P.A.; Primmer, E.; Barton, D.N.; Mononen, L.; Vihervaara, P.; Furman, E. Exploring operational ecosystem service definitions: The case of boreal forests. Ecosyst. Serv. 2015, 14, 144-157. [CrossRef]

22. Saastamoinen, O.; Lacuna-Richman, C.; Vaara, M. Is the use of forest berries for poverty mitigation a relevant issue in an affluent society such as Finland? In Non-Wood Forest Products and Poverty Mitigation: Concepts, Overviews and Cases; Lacuna-Richman, C., Turtiainen, M., Barszcz, A., Eds.; University of Joensuu: Joensuu, Finland, 2004; pp. 59-72.

23. Barszcz, A. An overview of the socio-economics of non-wood forest products in Poland. In Non-Wood Forest Products and Poverty Mitigation: Concepts, Overviews and Cases; Lacuna-Richman, C., Turtiainen, M., Barszcz, A., Eds.; University of Joensuu: Joensuu, Finland, 2004; pp. 1-20, Research Notes 166.

24. Kovalčík, M. Value of forest berries and mushrooms picking in Slovakia's forests. Beskydy 2014, 7, 39-46. [CrossRef]

25. Turtiainen, M.; Salo, K.; Saastamoinen, O. Variations of yield and utilisation of bilberries (Vaccinium myrtillus L.) and cowberries (V. vitis-idaea L.) in Finland. Silva Fenn. 2011, 45, 237-251. [CrossRef]

26. Ristioja, A. Toimialaraportti: Luonnontuoteala; Työ- ja Elinkeinoministeriö: Helsinki, Finland, 2017; p. 79.

27. Vaara, M.; Saastamoinen, O.; Turtiainen, M. Changes in wild berry picking in Finland between 1997 and 2011. Scand. J. For. Res. 2013, 28, 586-590. [CrossRef]

28. Mononen, L.; Auvinen, A.-P.; Ahokumpu, A.-L.; Rönkä, M.; Aarras, N.; Tolvanen, H.; Kamppinen, M.; Viirret, E.; Kumpula, T.; Vihervaara, P. National ecosystem service indicators: Measures of social-ecological sustainability. Ecol. Indic. 2016, 61, 27-37. [CrossRef]

29. Muir, G.F.; Sorrenti, S.; Vantomme, P.; Vidale, E.; Masiero, M. Into the wild: Disentangling non-wood termsand definitions for improved forest statistics. Int. For. Rev. 2020, 22, 101-119. [CrossRef]

30. Vauhkonen, J.; Ruotsalainen, R. Assessing the provisioning potential of ecosystem services in a Scandinavian boreal forest: Suitability and tradeoff analyses on grid-based wall-to-wall forest inventory data. For. Ecol. Manag. 2017, 389, 272-284. [CrossRef]

31. Chudy, R.P.; Hagler, R.W. Dynamics of global roundwood prices-Cointegration analysis. For. Policy Econ. 2020, 115, 102155. [CrossRef]

32. De Groot, M.; Diaci, J.; Ogris, N. Forest management history is an important factor in bark beetle outbreaks: Lessons for the future. For. Ecol. Manag. 2019, 433, 467-474. [CrossRef]

33. Dobor, L.; Hlásny, T.; Rammer, W.; Zimová, S.; Barka, I.; Seidl, R. Spatial configuration matters when removing windfelled trees to manage bark beetle disturbances in Central European forest landscapes. J. Environ. Manag. 2020, 254, 109792. [CrossRef]

34. Atlegrim, O.; Sjöberg, K. Response of bilberry (Vaccinium myrtillus) to clear-cutting and single-tree selection harvests in uneven-aged boreal Picea abies forests. For. Ecol. Manag. 1996, 86, 39-50. [CrossRef]

35. Lõhmus, A.; Remm, L. Disentangling the effects of seminatural forestry on an ecosystem good: Bilberry (Vaccinium myrtillus) in Estonia. For. Ecol. Manag. 2017, 404, 75-83. [CrossRef]

36. Nielsen, A.; Totland, Ø.; Ohlson, M. The effect of forest management operations on population performance of Vaccinium myrtillus on a landscape-scale. Basic Appl. Ecol. 2007, 8, 231-241. [CrossRef] 
37. Woziwoda, B.; Dyderski, M.K.; Jagodziński, A.M. Effects of land use change and Quercus rubra introduction on Vaccinium myrtillus performance in Pinus sylvestris forests. For. Ecol. Manag. 2019, 440, 1-11. [CrossRef]

38. Laughlin, P. Holistic customer insight as an engine of growth. J. Direct Data Digit. Mark. Pract. 2014, 16, 75-79. [CrossRef]

39. MZe. Zpráva o Stavu Lesa a Lesního Hospodárství Ceské Republiky v Roce 2015. Report on the Forestry of the Czech Republic in 2015. Ministry of Agriculture of the Czech Republic (MZe), Prague. 2016. Available online: http://www.uhul.cz/ke-stazeni/informace-o-lese/zelene-zpravy-mze/ (accessed on 15 January 2019). (In Czech).

40. Šišák, L.; Roček, I.; Stolina, M.; Pulkrab, K.; Hlaváček, S.; Šemrinec, J.; Kalivoda, V. Sociálně-Ekonomický Význam Produkce Lesa Mimo Dřevo v České Republice; Výzkumná zpráva, MZe, NAZV; Lesnická fakulta ČZU v Praze: Prague, Czech Republic, 1996; p. 159. (In Czech)

41. Šišák, L. Importance of non-wood forest product collection and use for inhabitants in the Czech Republic. J. For. Sci. 2006, 52, 417-426. [CrossRef]

42. Šišák, L. Význam produkce lesa kromě dřeva v České republice. Lesnictví For. 1997, 43, 49-66. (In Czech)

43. Sisak, L.; Riedl, M.; Dudik, R. Non-market non-timber forest products in the Czech Republic-Their socio-economic effects and trends in forest land use. Land Use Policy 2016, 50, 390-398. [CrossRef]

44. Everitt, B. The Cambridge Dictionary of Statistics; Cambridge University Press: Cambridge, UK, 1998; ISBN 978-0521593465.

45. Campbell, M.J.; Machin, D.; Walters, S.J. Medical Statistics: A Textbook for the Health Science; John Wiley \& Sons: Hoboken, NJ, USA, 2010.

46. Ministry of the Environment of the Czech Republic. Report on the Environment in the Czech Republic; MZP: Prague, Czech Republic, 2017; ISBN 978-80-87770-68-9. Available online: https://www.mzp.cz/C1257 50E003B698B/en/state_of_the_environment_reports_documents/\$FILE/OPZPUR-Report_CZ_Environment _2017-20190116.pdf (accessed on 15 April 2020).

47. CSO. Obyvatelstvo—Roční Časové Řady; Český Statistický Úřad: Prague, Czech Republic, 2020. Available online: https://www.czso.cz/csu/czso/obyvatelstvo_hu (accessed on 15 April 2020). (In Czech)

48. Department for Environment, Food and Rural Affairs. Survey of Public Attitudes and Behaviours toward the Environment, 2007; Computer File; Environment Statistics and Indicators Division and BMRB, Social Research; UK Data Archive; DEFRA: London, UK, 2007; SN. 5741. [CrossRef]

49. Agresti, A. Categorical Data Analysis, 2nd ed.; John Wiley \& Sons, Inc.: Hoboken, NJ, USA, 2002.

50. MZe. Zpráva o Stavu Lesa a Lesního Hospodářství České Republiky v Roce 2018. Report on the Forestry of the Czech Republic in 2018. Ministry of Agriculture of the Czech Republic (MZe), Prague. Available online: http://www.uhul.cz/ke-stazeni/informace-o-lese/zelene-zpravy-mze/ZZ_2018.pdf (accessed on 15 January 2020). (In Czech).

51. Gini, C. Variabilità e Mutabilità: Contributo allo Studio delle Distribuzioni e delle Relazioni Statistiche; P. Cuppini: Bologna, Italy, 1912.

52. O'Donnell, O.; O'Neill, S.; Van Ourti, T.; Walsh, B. Conindex: Estimation of Concentration Indices. Stata J. 2016, 16, 112-138. [CrossRef]

53. Campano, F.; Salvatore, D. Income Distribution; Oxford University Press: Oxford, UK, 2006.

54. Biewen, M. Bootstrap inference for inequality, mobility and poverty measurement. J. Econ. 2002, 108, 317-342. [CrossRef]

55. Sadras, V.; Bongiovanni, R. Use of Lorenz curves and Gini coefficients to assess yield inequality within paddocks. Field Crop. Res. 2004, 90, 303-310. [CrossRef]

56. Lorenz, M.O. Methods of measuring the concentration of wealth. Publ. Am. Stat. Assoc. 1905, 9, $209-219$. [CrossRef]

57. Jann, B. Estimating Lorenz and Concentration Curves. Stata J. 2016, 16, 837-866. [CrossRef]

58. R Core Team. R: A Language and Environment for Statistical Computing; R Foundation for Statistical Computing: Vienna, Austria, 2018.

59. Venables, W.N.; Ripley, B.D. Modern Applied Statistics with S, 4th ed.; Springer: New York, NY, USA, 2002; p. 504.

60. Stiger, T.R.; Barnhart, H.X.; Williamson, J.M. Testing proportionality in the proportional odds model fitted with GEE. Stat. Med. 1999, 18, 1419-1433. [CrossRef] 
61. Hartigan, J.A.; Kleiner, B. Mosaics for contingency tables. In Computer Science and Statistics, Proceedings of the 13th Symposium on the Interface, Pittsburg, CA, USA, 12-13 March 1981; Eddy, W.F., Ed.; Springer: New York, NY, USA, 1981; pp. 268-273.

62. Friendly, M. Mosaic displays for multi-way contingency tables. J. Am. Stat. Assoc. 1994, 89, $190-200$. [CrossRef]

63. Wallenius, T.H. Yield variations of some common wild berries in Finland in 1956-1996. Ann. Bot. Fenn. 1999, 36, 299-314.

64. CHMI. Historical Data-Meteorology and Climatology. 2019. Available online: http://portal.chmi.cz/histori cka-data/pocasi/zakladni-informace?l=en (accessed on 23 August 2019).

65. Burnham, K.P.; Anderson, D.R. Model Selection and Multi-Model Inference: A Practical Information-Theoretic Approach, 2nd ed.; Springer: New York, NY, USA, 2002.

66. Akaike, H. What is an information criterion AIC. Math. Sci. 1976, 14, 5-11.

67. Holub, K.; Rušajová, J.; Sandev, M. A comparison of the features of windstorms Kyrill and Emma based on seismological and meteorological observations. Meteorol. Z. 2009, 18, 607-614. [CrossRef]

68. eAGRI. Pomoc pro Vlastníky Lesů Postižených Kưrovcovou Kalamitou: Ministerstvo Zemědělství Jim dá 2,5 Miliardy Korun na Nové Zalesnění a Péči o Lesy; Ministerstvo zemědělství: Prague, Czech Republic, 2019. Available online: http://eagri.cz/public/web/mze/tiskovy-servis/tiskove-zpravy/x2019_pomoc-pro-vlastniky-lesu-p ostizenych.html (accessed on 21 May 2020). (In Czech)

69. Horák, V.; Lhota, T. Monitoring of red deer (Cervus elaphus) environment in the Giant Mountain using GIS analysis. Opera Corcon. 2006, 43, 111-135. (In Czech)

70. KRNAP. Opatření Obecné Povahy č. 1/2015-Omezení Vstupu z Důvodu Ochrany Př́rody. 2015. Available online: https://www.krnap.cz/data/File/legislativa/2015/oop_1_2015.pdf (accessed on 2 November 2018). (In Czech).

71. Rychtera, Z. Omezení Vstupu Kvůli Sběračům Borůvek Letos v Krkonoších Nebude. 2018. Available online: http://www.enviweb.cz/111766 (accessed on 8 November 2019). (In Czech).

72. Nichiforel, L.; Keary, K.; Deuffic, P.; Weiss, G.; Thorsen, B.; Winkel, G.; Avdibegovic, M.; Dobsinska, Z.; Feliciano, D.; Gatto, P.; et al. How Private Are Europe's Private Forests? A Comparative Property Rights Analysis. Land Use Policy 2018, 76, 535-552. [CrossRef]

73. Velde, D.W.T.; Rushton, J.R.; Schreckenberg, K.; Marshall, E.; Edouard, F.; Newton, A.; Arancibia, E. Entrepreneurship in value chains of non-timber forest products. For. Policy Econ. 2006, 8, 725-741. [CrossRef]

74. Gejdos, M.; Lieskovsky, M.; Giertliova, B.; Nemec, M.; Danihelova, Z. Prices of Raw-wood Assortments in Selected Markets of Central Europe and their Development in the Future. BioResources 2019, 14, 2995-3011.

75. Hlavackova, P.; Brezina, D.; Sujova, A. The Price Formation of Raw Wood in the Czech Republic and a Comparison with the Neighbor States. Proc. Econ. Finance 2015, 26, 389-395. [CrossRef]

76. CZSO. 2019; Indexy cen v Lesnictví (Surové Dřiví). Český Statistický Úřad. Available online: https://www. czso.cz/documents/10180/91605347/01103519q1g1.pdf/c820568a-9fb3-4996-a532-45eae9ed298f?version=1.0 (accessed on 20 May 2019). (In Czech)

77. Župančič, E. Co Čech, to Chalupář. Platí Ještě Toto Tvrzení? Dřevostavitel. Brno: NETION. 2018. Available online: https:/www.drevostavitel.cz/clanek/chaty-a-chaticky-fotogalerie (accessed on 13 April 2020). (In Czech).

78. Vágner, J.; Müller, D.K.; Fialová, D. Second home tourism in light of the historical-political and socio-geographical development of Czechia and Sweden. Geografie 2011, 116, 191-210. [CrossRef]

79. Kubeš, J. Chatové oblasti České republiky. Geogr. Časopis 2011, 63, 53-68. (In Czech)

80. Šišák, L. Forest visitors' opinions on the importance of forest operations, forest functions and sources of their financing. J. For. Sci. 2011, 57, 266-270. [CrossRef]

81. Kuesten, C.; Bi, J.; Meiselman, H.L. Analyzing consumers' Profile of Mood States (POMS) data using the proportional odds model (POM) for clustered or repeated observations and $\mathrm{R}$ package 'repolr'. Food Qual. Preference 2017, 61, 38-49. [CrossRef]

82. Salo, K. Valtakunnalliset marja-ja sienisatoennusteet. In Metsä. Monikäyttö Ja Ekosysteemipalvelut; Salo, K., Ed.; Fluke Corporation: Hauppauge, NY, USA, 2015; pp. 128-130.

83. Miina, J.; Hotanen, J.-P.; Salo, K. Modelling the abundance and temporal variation in the production of bilberry (Vaccinium myrtillus L.) in Finnish mineral soil forests. Silva Fenn. 2009, 43, 577-593. [CrossRef] 
84. Salemaa, M. Vaccinium myrtillus. Mustikka. In Kasvit Muuttuvassa Metsäluonnossa; Reinikainen, A., Mäkipää, R., Vanha-Majamaa, I., Hotanen, J.-P., Eds.; Tammi: Helsinki, Finland, 2000; pp. 128-130.

85. Juutinen, A.; Kosenius, A.-K.; Ovaskainen, V.; Tolvanen, A.; Tyrväinen, L. Heterogeneous preferences for recreation-oriented management in commercial forests: The role of citizens' socioeconomic characteristics and recreational profiles. J. Environ. Plan. Manag. 2017, 60, 399-418. [CrossRef]

86. Kangas, J.; Kangas, A. Multiple Criteria Decision Support Methods in Forest Management. In Multi-Objective Forest Planning: Managing Forest Ecosystems; Pukkala, T., Ed.; Springer: Dordrecht, The Netherlands, 2002; Volume 6.

87. Kurttila, M.; Tahvanainen, V. (Eds.) Description of New Decision Support Tools for Optimization of MPT and NWFP Management; Deliverable 2.4. FP7 Project no 311919 KBBE.2012.1.2-06; European Commission: Brussels, Belgium, 2016; p. 106.

88. Miina, J.; Pukkala, T.; Hotanen, J.-P.; Salo, K. Optimizing the joint production of timber and bilberries. For. Ecol. Manag. 2010, 259, 2065-2071. [CrossRef]

89. Feliciano, D.; Bouriaud, L.; Brahic, E.; Deuffic, P.; Dobšinská, Z.; Jarský, V.; Lawrence, A.; Nybakk, E.; Quiroga, S.; Suárez, C.; et al. Understanding private forest owners' conceptualisation of forest management: Evidence from a survey in seven European countries. J. Rural. Stud. 2017, 54, 162-176. [CrossRef]

90. Matilainen, A.; Koch, M.; Zivojinovic, I.; Lähdesmäki, M.; Lidestav, G.; Karppinen, H.; Didolot, F.; Jarsky, V.; Põllumäe, P.; Colson, V.; et al. Perceptions of ownership among new forest owners-A qualitative study in European context. For. Policy Econ. 2019, 99, 43-51. [CrossRef]

91. Šišák, L. Aktuálnía Strategické Možnosti Trvale Udržitelného Poskytování Funkcí Lesa a Služeb Polyfunkčního Lesního Hospodářství Veřejnosti z Hlediska Sociálně-Ekonomického, Politického a Právního v České Republice; Redakčně upravená závěrečná zpráva o řešení projektu NAZV č. QJ1530032; Česká Zemědělská Univerzita v Praze: Prague, Czech Republic, 2018; p. 90. (In Czech)

92. Alexander, S.J.; Pilz, D.; Weber, N.S.; Brown, E.; Rockwell, V.A. Mushrooms, Trees, and Money: Value Estimates of Commercial Mushrooms and Timber in the Pacific Northwest. Environ. Manag. 2002, 30, $129-141$. [CrossRef]

93. De Frutos, P.; Rodríguez-Prado, B.; Latorre, J.; Martinez-Peña, F. Environmental valuation and management of wild edible mushroom picking in Spain. For. Policy Econ. 2019, 100, 177-187. [CrossRef]

94. Peura, M.; Triviño, M.; Mazziotta, A.; Podkopaev, D.; Juutinen, A.; Mönkkönen, M. Managing boreal forests for the simultaneous production of collectable goods and timber revenues. Silva Fenn. 2016, 50, 1672. [CrossRef]

95. Gatto, P.; Pettenella, D.; Secco, L. Payments for forest environmental services: Organisational models and related experiences in Italy. iForest 2009, 2, 133-139. [CrossRef]

96. Vidale, E.; Da Re, R.; Pettenella, D. Trends, Rural Impacts and Future Developments of Regional WFP Market. Project Deliverable D3.3. StarTree Project (EU Project 311919). 2015. Available online: https://www.research gate.net/publication/327136729_D33_Trends_rural_impacts_and_future_developments_of_regional_WF P_market_StarTree_Multipurpose_trees_and_non-wood_forest_products_a_challenge_and_opportunity (accessed on 7 October 2020).

97. Mantau, U.; Merlo, M.; Sekot, W.; Welcker, B. Recreational and Environmental Markets for Forest Enterprises. A New Approach Towards Marketability of Public Goods; CABI Publishing: Walingford, UK, 2001; p. 418.

98. Vidale, E.; Riccardo, D.R.; Lovric, M.; Pettenella, D. NWFP in the International Market: Current Situation and Trends; University of Padova: Padova, Italy, 2016.

99. Nichiforel, L.; Deuffic, P.; Thorsen, B.J.; Weiss, G.; Hujala, T.; Keary, K.; Lawrence, A.; Avdibegović, M.; Dobšinská, Z.; Feliciano, D.; et al. Two decades of forest-related legislation changes in European countries analysed from a property rights perspective. For. Policy Econ. 2020, 115, 102146. [CrossRef]

100. Hamunen, K.; Kurttila, M.; Miina, J.; Peltola, R.; Tikkanen, J. Sustainability of Nordic non-timber forest product-related businesses-A case study on bilberry. For. Policy Econ. 2019, 109, 102002. [CrossRef]

101. Kilpeläinen, H.; Salminen, O.; Härkönen, K.; Miina, J.; Kurttila, M. Integrating bilberry yields into regional long-term forest scenario analyses. Scand. J. For. Res. 2018, 33, 378-386. [CrossRef]

102. Tahvanainen, V.; Miina, J.; Kurttila, M. Climatic and Economic Factors Affecting the Annual Supply of Wild Edible Mushrooms and Berries in Finland. Forests 2019, 10, 385. [CrossRef] 
103. Sarvašová, Z.; Živojinović, I.; Weiss, G.; Dobšinská, Z.; Drăgoi, M.; Gál, J.; Jarský, V.; Mizaraite, D.; Põllumäe, P.; Šálka, J.; et al. Forest Owners Associations in the Central and Eastern European Region. Small-Scale For. 2015, 14, 217-232. [CrossRef]

104. Schlager, E.; Ostrom, E. Property-Rights Regimes and Natural Resources: A Conceptual Analysis. Land Econ. 1992, 68, 249-262. [CrossRef]

Publisher's Note: MDPI stays neutral with regard to jurisdictional claims in published maps and institutional affiliations.

(C) 2020 by the authors. Licensee MDPI, Basel, Switzerland. This article is an open access article distributed under the terms and conditions of the Creative Commons Attribution (CC BY) license (http://creativecommons.org/licenses/by/4.0/). 